\title{
アルミニウムータングステン繊維系複合合金における 繊維のアスペクト比と強度との関係*
}

\author{
三浦維四** 本間久夫块平野 進**
}

Ishi Miura, Hisao Honma and Susumu Hirano: The Relations between the Aspect Ratio of Fibers and Tensile Strength in Tungsten-Fiber-Reinforced Aluminum Composites. In order to investigate the relations between the aspect ratio of the tungsten fiber and the tensile strength in tungsten-fiber-reinforced aluminum composites, specimens were made by means of a foil metallurgy technique which has already been reported ${ }^{(1)}$. The sandwiches of aluminum foils with the tungsten fibers were changed by rolling reduction. The used fibers were $10,25,50,100$ and $200 \mu$ in diameter and their aspect ratios ranged from 15 to 35 . The results were as follows :

(1) The tensile strength of the composites increased linearly to the volume fraction of the tungsten fiber in composites, and also increased with the aspect ratio of the tungsten fibers. (2) The tensile strength was higher than that calculated on the basis of Kelly's theory. These results imply that the elastic stress transfer in the fiber plays a more important role in discontinous fibers, especially with low aspect ratio in composites.

(Received May 29, 1969)

\section{I. 緒 言}

㵶維強化合金は従来の合金と比較すると，その強化機構 が全く異なっている。この型の合金の強化に括よぼす因子 としては緎維の強さ，㵶維の割合などの他に，瀻維の整列 性, 分布状況などが考えられているが，とくに䋐維が非連 続の形である場合にはアスペクト比 (繊維の長さ/直径) が 大きく影響することが知られているが，その報告はごくわ ずかで二,三の例があるだけである(2) (4). 著者ら(1) はいま まで金属箔を主原料とし，圧延あるいは圧接法によってタ ングステンーアルミニウム系複合体を作り，その複合体の 引張強さ，クリープ強さなどの機伐的性質を調べてきた。 本報告では瀻維のアスペクト比の影響を調べる目的で前報 告 ${ }^{(5)}$ と同じく圧延によってタングステンーアルミニウム系 複合体を作りこの場合の压延率を変光ることによってタ ングステン線のアスペクト比を変え，これらの試料につい て引張強さを調べた結果について述べる.

\section{II. 実 娩方法および結 果}

この報告で採用した試験片の作り方，素材は前報 ${ }^{(5)} て ゙$ 述 べたものと同じであり，用いたアルミニウム䇴は $7 \mu$ の厚

** 東京医科歯科大学医用器材研究所 (Tok yo Medical and Dental University, Institute for Medical and Dental Engineering, Tokyo)

* 1968 年 5 月軽金属学会高岡大会飞発表; 金属組織と 機械的性質の関係沉つて(第 15 報)

（1）三浦，太田，本間，佐々木：金属学会誌，30(1966), 655.

(2) A.Kelly : Proc. Roy.Soc., A 282 (1964), 63.

(3) A.Kelly and W.R.Tyson : High Strength Material, (1964), 578.

(4) D.L.McDanels et al : Trans. Met.Soc. AIME, 233 (1965), 630.

（5）三浦，本間：金属学会誌，31(1967)，475.
さのものである．繊維として用いたタングステン線の直径 は $10,25,50,100,200 \mu$ の 5 種類のものである. タングス テン線の配合率は体積にして $10 \%$ と $15 \%$ のものを作り， タングステン線をアルミ䈃の間にはさみ込み, $500^{\circ} \mathrm{C} に て$ 数回圧延して複合体を得た。㵶維のアスペクト比は 15～35 でありこれは圧延による加工度を变えることにより得ら れた，压延加工度は 45～75\% である，複合体中の㵶維の アスペクト比は $30 \%$ 塩酸溶液中でアルミニウムを溶かし， タングステン線を取り出して測定した.

Fig.1 はこれらの複合体の応力ーひずみ線図を示したも のである. 図中 $7 \mu \mathrm{Al}$ と記されているものは $7 \mu$ の厚さ のアルミニウム䇴のみを压延して作ったものであり， $L / d$ $=\infty$ と記されているものは連続纎維を体積割合で 10\%(以

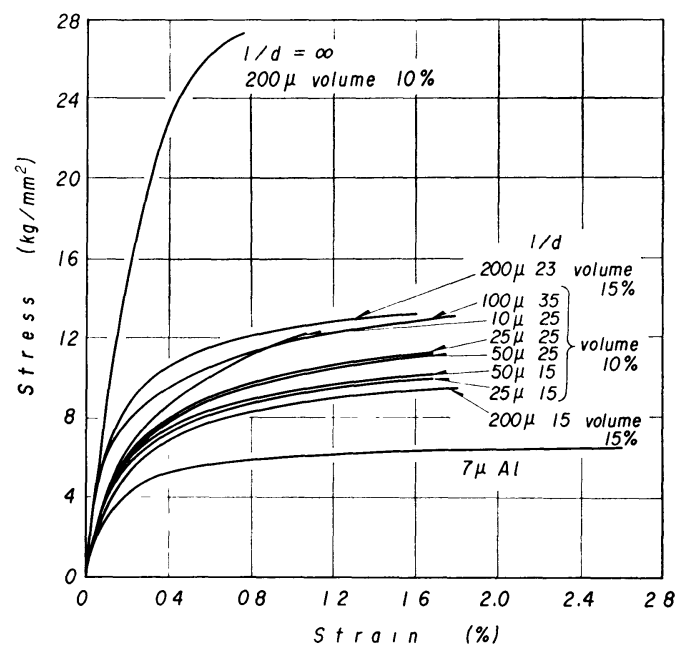

Fig.1 Stresss-strain curves of aluminum composites containing various discontinuous tungsten fibers 
下すべて体積割合で示し vo1\%と略す)含んだものである. 図よりタングステン線を同じ割合で含むるのではアスペク 卜比 $L / d$ の值が大きいものの方が引張強さが大きくなる 傾向がある。また応力ーひずみ線図は連続繊維の場合に比 較してアスペクト比の小さいるのの方がアルミニウムマト リックスのそれに近い挙動をするようである。

Fig.2 は複合体の引張強さと繊維の体積割合の関係を 示したものである，連続織維の場合と同じく，非連続䋐 維の場合もやはり絨維の割合が增えると引張強さが增え ることがわかるが，織維の直径による違いはFig.1 と同 様見られず，むしろアスペクト比の大きいるのの方が弓

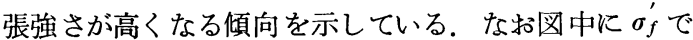
示されているのはこれら複合体の引張試験結果から外挿 して得られる瀻維自体の強さを表わしている。 また $\sigma_{m}^{\prime}$ は㵶維の破断強さ $\sigma_{f}$ のときの伸びに相当する伸びをマ トリックスに与えたときのマトリックスの応力である.

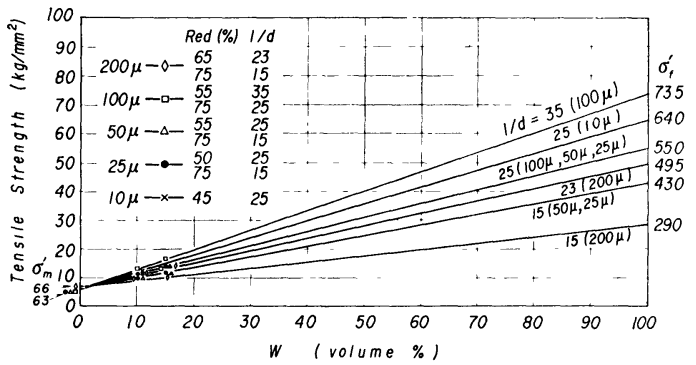

Fig.2 Effect of the amount of tungsten fibers on the tensile strength of aluminum composites containing tungsten fibers with various aspect ratios

Table 1 は複合体に使用した各 $く$ 径のタングステン線 について複合体作製時における压延加工度, アスペクト比, 繊維の強さ $\sigma_{f}$ などについてまとめたものである。 $l_{c} / d$ は 臨界アスペクト比で, $m$ は䋐維の全長 $L$ 亿対する臨界伝達 長さ(critical transfer length)である. 繊維の強さ $\sigma_{f}$ は直 径が同じものでは複合体作製のための圧延加工度が大きい ものの方が小さく，直径のちがうものとの違いははっきり と認められていない.
Fig.3 は同様に複合体のヤング率と緎維の体積割合につ いて測定した結果である。これはインストロン型引張試験 機に差動トランスを応用した精密伸び計によって応力ーひ ずみ曲線を求め, これからヤング率の值を求めたものであ る.

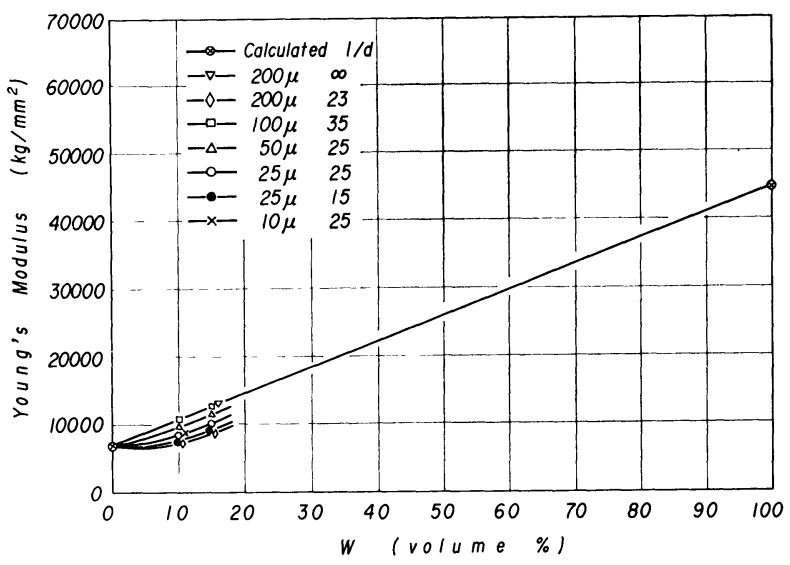

Fig.3 Effect of the amount of tungsten fiber on the Young's modulus of aluminum composites containing tungsten fibers with various aspect ratios

複合体のヤング率 $E_{c}$ は複合法則 $E_{c}=E_{f} V_{f}+E_{m}\left(1-V_{f}\right)$ で表わされ，織維量の増加によってヤング率も增加するこ とを示している。 な括 $E_{f}, E_{m}$ はそれぞれ䋐維拉よびマト リックスのヤング率で $V_{f}$ は㵶維の体積割合である．眓中 calculated で示された直線は複合法則に基づくもので, $E_{m}=7000 \mathrm{~kg} / \mathrm{mm}^{2}, E_{f}=45000 \mathrm{~kg} / \mathrm{mm}^{2}$ で計算してある. 直径 $200 \mu$ で連続䋐維としてタングステン線を含む複合体 と, 直径 $100 \mu$ でアスペクト比が 35 の複合体については ほぼ複合法則にしたがうが，他のものではヤング率はいず れも下回っていて，これはさきに報告したものに执いても 同じような結果が得られている。.とくに直径 $200 \mu$ でタン

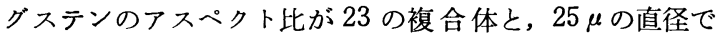
アスペクト比が 15 のタングステン線を含む複合体に打い てはヤング率が低く，非連続䋐維を含む複合体に括いて

Table 1 Properties of reinforcing tungsten fibers

\begin{tabular}{c|c|c|c|c|c|c|c|c}
\hline $\begin{array}{c}\text { Diameter } \\
(\mu)\end{array}$ & $\begin{array}{c}\text { Reduction } \\
(\%)\end{array}$ & $\begin{array}{c}\text { Aspect ratio } \\
(1 / d)\end{array}$ & $\begin{array}{c}\sigma_{m} \\
\left(\mathrm{~kg} / \mathrm{mm}^{2}\right)\end{array}$ & $\begin{array}{c}\sigma_{f} \\
\left(\mathrm{~kg} / \mathrm{mm}^{2}\right)\end{array}$ & $\begin{array}{c}\sigma_{f}^{\prime} \\
\left(\mathrm{kg} / \mathrm{mm}^{2}\right)\end{array}$ & $\begin{array}{c}V_{f} \text { crit } \\
(\%)\end{array}$ & $\begin{array}{c}m \\
(1 / L)\end{array}$ & $\left(_{c} / d\right)$ \\
\hline 200 & 65 & 23 & 6.6 & 65 & 49 & 2.8 & 0.43 & 9.8 \\
& 75 & 15 & 6.6 & 41 & 29 & 4.6 & 0.41 & 6.2 \\
\hline \multirow{2}{*}{100} & 55 & 35 & 6.3 & 86 & 73 & 2.3 & 0.39 & 13.7 \\
& 75 & 25 & 6.3 & 73 & 55 & 3.0 & 0.46 & 11.6 \\
\hline \multirow{2}{*}{50} & 55 & 25 & 6.3 & 73 & 55 & 3.0 & 0.46 & 11.6 \\
& 75 & 15 & 6.3 & 61.5 & 43 & 3.8 & 0.65 & 9.8 \\
\hline \multirow{2}{*}{25} & 50 & 25 & 6.3 & 73 & 55 & 3.0 & 0.46 & 11.6 \\
& 75 & 15 & 6.3 & 61.5 & 43 & 3.8 & 0.65 & 9.8 \\
\hline 15 & 45 & 25 & 6.3 & 85 & 64 & 2.6 & 0.54 & 13.5 \\
\hline
\end{tabular}


は，そのヤング率はや仕り䋐維のアスペクト比となんらか の関保があるのではないかと考えられる。

Photo.1 は試験に供した複合体の横断面の蹎微鏡写真 でタングステン線の含有量はいずれる10 vol\% でする。 丸印に見えるのがタングステン線で，そのまわりに黒く見 えるのは，研摩の際にアルミニウムの部分が摩耗したもの で, 複合体作製の祭のタングステンとアルミニウムとの反 応層ではない。

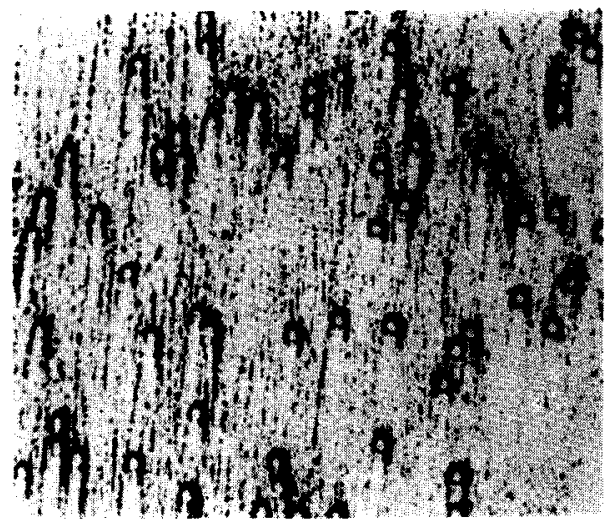

$10 \% 10 \mu \mathrm{W}$ Red. $50 \%(\times 150)$

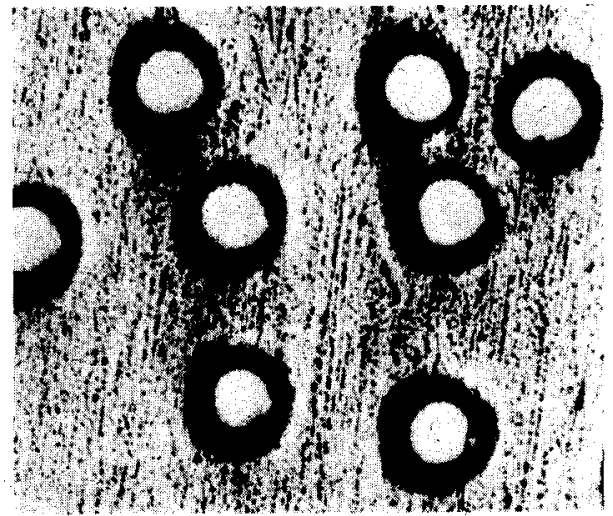

$10 \% 50 \mu \mathrm{W}$ Red. $55 \%(\times 150)$ $\sigma_{f}, V_{f}$ は䄉維の強さと複合体中にしめる瀻維の体積割合 である。また $L$ は蟣維の全長で， $L_{c}$ は臨界の䋐維長さで

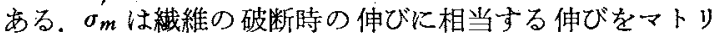
ックスに与えたとさのマトリックスの応力である。

この式より $L$ の長さが $L_{c}$ の 10 倍に相当すると連続緎 維による強化の場合の $95 \%$ の強化が可能であることが示 されている.

このとさ臨界アスペクト比，瀻維の強さとマトリックス

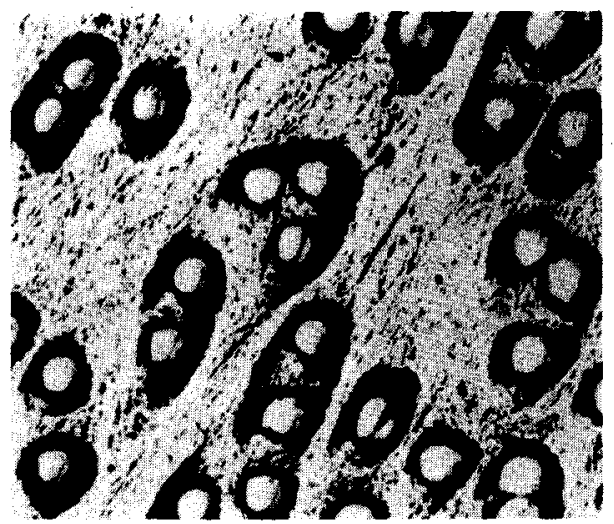

$10 \% 25 \mu \mathrm{W}$ Red. $50 \%(\times 150)$

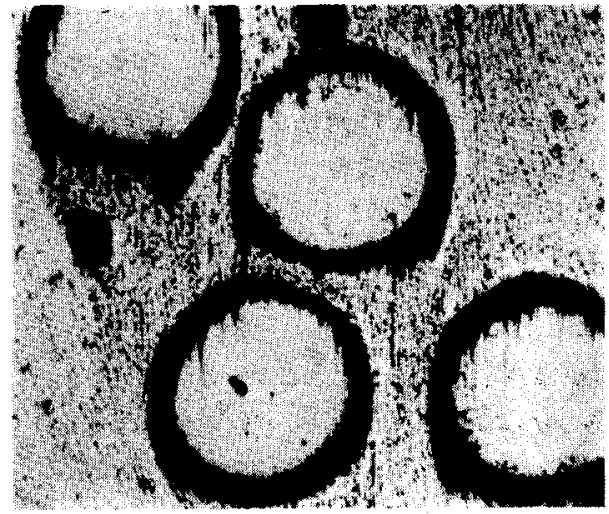

$10 \% 100 \mu \mathrm{W}$ Red. $55 \%(\times 150)$

Photo. 1 Cross-section of Al composites containing $10 \% \mathrm{~W}$ fiber with various diameters

III. 考察

䋐維が連続でなく非連続の場合でも強化が可能であると いうことは，織維強化合金の発展にとって大きな発見であ った，非連続䋐維に敊ける強化の考え方はマトリックスか ら緉維への応力伝播によって研究されてきている. Kelly ${ }^{(6)}$ はマトリックスから緎維への応力の伝達はマトリックスの plastic flow によって起こると仮定して，1本の䋐維にか かる応力分布を簡単な“台形近似”によるモデルとして考 えて，よく知られた非連続緎維を含む場合の複合体の引張 强さ $\sigma_{c}$ を導き出している。すなわち

$$
\sigma_{c}=\sigma_{f} V_{f}\left(1-\begin{array}{c}
L_{c} \\
2 L
\end{array}\right)+\sigma_{m}{ }^{\prime}\left(1-V_{f}\right)
$$

(6) A. Kelly and G.Davies : Metall.Rev., 10(1965), 1.
のせん断強さの間には $L_{c} / d=\sigma_{f} / 2 \tau の$ 関係がありこの式 をアスペクト比 $p(=L / d)$ に関係させた式を導くことにす る。すなわち $L_{c}=\left(\sigma_{f} d\right) / 2 \tau$ を代入すると

$$
\sigma_{c}=\frac{a \sigma_{f}}{1+a}\left(1-\frac{\sigma_{f}}{4 p \tau}\right)+\frac{\sigma_{m}}{1+a}
$$

この式では $V_{f}=a / 1+a$ なる形で表わしている、aはマ トリックスの体積割合を 1 とした時の絾維の占める体積を 表わするのである。

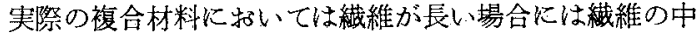
心付近ではマトリックスと㵶との間の変位は少ないこと が知られている。最近Piggott(7) は織維の端近くでは Kelly と同じくマトリックスは plastic flowをするが，中心部付 近では elasticである⿸尹口考えたモデルを発表し，そのモデ

(7) M.R.Piggott : Acta Met., 14(1966), 1429. 
ルの適合性について計算を行なった。

Fig.4は彼の考光たモデルを示したもので，ここでは $\mathrm{AOA}^{\prime}$ に执いては elastic であり, $\mathrm{AB}, \mathrm{A}^{\prime} \mathrm{B}^{\prime}$ に打いては Kelly と同じく plastic flowによっていると考兄られてい る. Kelly との相異は $\mathrm{AOA}^{\prime}$ の部分についてであり，この 部分で破線で示されているのが Kelly の考えたモデルであ る.この $\mathrm{AOA}^{\prime}$ に拈いて Piggott の考えたモデルの方が㵶 維の応力分布が大きくなっている。ここで紼維にかかる応 力を計算してみると， $\mathrm{AB}$ のような plastic flow 部分では $\mathrm{B}$ から $\mathrm{A}$ への応力分布は直線的に増加するので， $\mathrm{AB}$ に抹 いては織維にかかる応力はつぎの上5に表わされる。

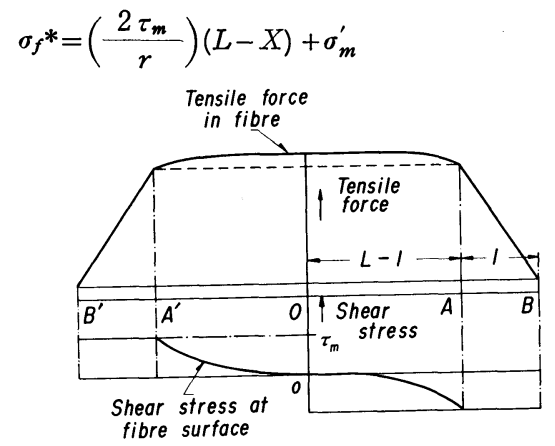

Fig.4 Schematic representation of interfacial shear stress $(\tau)$ and fiber tensile stress $\left(\sigma_{f}\right)$ (after Piggott)

つぎに OAに打いてはFig.3でわかるよ5に緎維にかか るせん断応力 $\tau$ は $\tau_{m}$ 以下であるので, この部分では $\operatorname{Cox}^{(8)}$ による弾性的な取扱いをして $\sigma_{f}^{*}$ を求めた。すなおち

$$
\begin{aligned}
\sigma_{f} *= & \frac{2 l}{r} \tau_{m}+\sigma_{m}^{\prime}+\frac{2 \tau_{m}}{\beta r}\left(1-\frac{\cosh \beta X}{\cosh \beta(L-l)}\right) \\
& \operatorname{coth} \beta(L-l)
\end{aligned}
$$

ここに $r$ は綫維の半径であり, $\beta$ は $\beta^{2}=H / E_{f} \cdot \pi r^{2}$ で示 されるもので, $E_{f}$ は䋐維のヤング率, $H$ は $H=4 \pi G / \log$

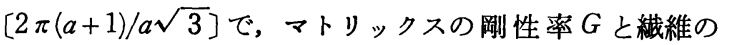
体積割合 $a$ に関係するすのであることがわかる.

この(4)式の elastic に応力の伝達をうける部分とさきの (3)式の plastic flow によって応力の伝達を 合わせると一本の㵶維が負担する全応力がわかり，それに よって単位長さにかかる平均の応力 $\sigma_{f}$ を計算してみると，

$$
\begin{aligned}
\bar{\sigma}_{f}= & \sigma_{m}^{\prime}+\frac{l}{L r} \tau_{m}(2 L-l) \\
& +\frac{2 \tau_{m}}{\beta^{2} r L}[\beta(L-l) \operatorname{coth} \beta(L-l)-1]
\end{aligned}
$$

一方マトリックスの平均の応力 $\bar{\sigma}_{m}$ はマトリックスと䋐 維のひずみが全体として同じであると考えると，つぎの式 が成立して $\bar{\sigma}_{f}$ の函数として表わされるよ5になる.

$$
\varepsilon=\frac{\bar{\sigma}_{m}}{E_{m}}=\frac{\bar{\sigma}_{f}}{E_{f}} \text { より } \quad \bar{\sigma}_{m}=\frac{E_{m}}{E_{f}} \bar{\sigma}_{f}
$$

そこで複合体の強さ $\sigma_{c}$ を $\sigma_{c}=\left(a \sigma_{c}+\bar{\sigma}_{m}\right) /(1+a)$ の式より 求めてみる. $\sigma_{m}^{\prime} \approx 2 \tau_{m}$ とすると

(8) H.L.Cox : Br.J.Appl.Phys., 3 (1962), 72.

$$
\begin{aligned}
\bar{\sigma}_{c}= & 2 \tau_{m} \cdot \frac{a+\frac{E_{m}}{E_{f}}}{1+a}\left[1+m p\left(1-\frac{m}{2}\right)\right. \\
& \left.+\frac{1}{n^{2} p}(n p(1-m) \operatorname{coth} n p(1-m)-1)\right]
\end{aligned}
$$

ここで $m$ は $m=l / L$ これは緘維の全長に対する plastic flow によって応力の伝達をうける部分の割合を示するの である. $n$ は $n=r \beta$ なるあので置換したものであり, $n^{2}=$ $4 G / E_{f} \log [2 \pi(a+1) / a \sqrt{3}]$ で示される.この $n$ は $G_{f} / E_{f}$ の平方根に比例するが $a$ にはほとんど無関係で, 䋐維の体 積割合にはとれほど影響されないことを示している. また $n \rightarrow 0$ になる時には elastic な応力伝達が最大になり, $n=$ 1.0 のときには elastic な応力伝達が全くないということ になる．またアスペクト比 $p$ にいては $n$ が 0.1 以下では $p=100$ 以上で, また $n=0.03$ では $p=300$ 以上で複合体の 強化の割合が一定となる。

繊維にかかる最大応力 $\sigma_{f \max }$ は Fig.4 で示されるように 絾維の中心部で生じることが明らかで, この部分でせん断 応力はゼロになっている， $\sigma_{f \max }$ は(4)式より導かれ，

$$
\sigma_{f \max }=2 \tau_{m}\left[1+m p+\frac{1}{n} \tanh \frac{n p}{2}(1-m)\right]
$$

この式を使って(1)式で示される Kelly の緎維の臨界長 さ (critical transfer length) $L_{c}$ との比較を行ってみる. $m=$ $l / L$ であり, $l$ は plastic flow によって応力を伝達する部 分の長さであるので, Kelly の織維の臨界長さ $L_{\boldsymbol{c}}$ とみな すことができる. そのため $L_{c}=m_{c} L$ となり，この $m_{c}$ を臨 界応力伝達比と呼ぶことにする。

一本の繊維にかかる最大応力 $\sigma_{f \max }$ が瀻維の破断強さ $\sigma_{f}$ に等しい時に破断するのが可能であると考えると $m_{\mathrm{c}} p$ $=L_{c} / d=\sigma_{f} / 2 \tau_{m}$ より(8)式はつぎのよ5に展開できる.

$$
m_{\mathrm{c}} p=\frac{\sigma_{f}}{2 \tau_{m}}=1+m p+\frac{1}{n} \tanh \frac{n p}{2}(1-m)
$$

一般の繊維すなわち臨界伝達長さ(critical transfer length) 以上の長さの緎維では $\tanh (n p / 2)(1-m) \rightarrow 1$ であ るのでつぎの $(10)$ 式のよ5に展開される.

$$
\frac{m_{c}-m}{m}=\frac{1+\frac{1}{n}}{\frac{\sigma_{f}}{2 \tau_{m}}-1-\frac{1}{n}}
$$

この式より $\sigma_{f} / 2 \tau_{m}$ と $n$ が比較的低い場合には elasticな 伝達による部分の影響が大きいことがわかる.

Fig. 5 は複合体の強さ $\sigma_{c}$ をマトリックスの強さ $\sigma_{m}$ で 除したもの，すなわち複合体による強化の割合を縦軸にと り, 横軸には $m$ をとり, 㵶維の長さすなわちアスペクト 比によって強化の割合がどのように変化するか調べたすの である。

この場合も直径 $100 \mu$ のタングステン線について, アス ペクト比 $p$ が 25〜300 までの範井で $10 \mathrm{vol} \%, 15 \mathrm{vol} \%$ の タングステン線を含む複合体について調べたが，アスペク ト比が大きくなると強化される割合る大きくなるのは当然 
であるが,やはりアスペクト比が 100 以上になるとのの 值がわずかに大きくなるだけで急激に強化されることがわ かる. フスペクト比が 25 拉よび 35 のあのでは，mの値の 変化によってもそれはど強化の割合は变化していないな お $m=1$ の場合は全域が plastic flowによって応力が伝 達される場合で Kellyの臨界伝達長さ (critical transfer length)に相当するるのである. (9)式より計算される臨界 芯力伝達比 $m_{c}$ と $p=35$ の場合の試験した複合体の $m$ と は活涩一致した值となり，この場合はマトリックスの2 倍 程度をで複合体によって強化されるようになる。

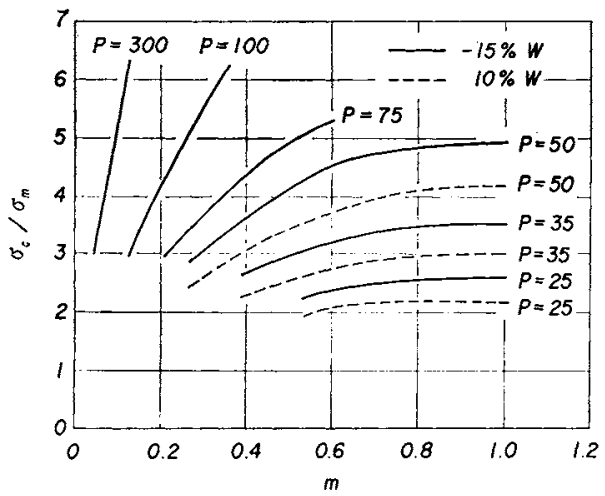

Fig. 5 The relations between strengthening factor $\left(\sigma_{c} / \sigma_{m}\right)$ and the value of $m(m=1 / L, 1=$ plastic stress transfer length, $2 L=$ fiber length)

Kelly による理論と Piggott によるものと実験值とを比 較したのが Fig.6である。これは直径 $100 \mu$ ，フスペクト 比 35 のタングステン線を含む複合体の場合汇ついて調べ たものである、マトリックスの朋性率は $2700 \mathrm{~kg} / \mathrm{mm}^{2}$ ，ヤ ング率は $7000 \mathrm{~kg} / \mathrm{mm}^{2}$ で, タングステン線のヤング率を

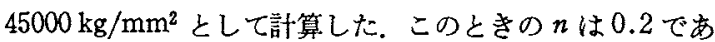
り，緎維の体積割合が変化してもほとんど変化がないのは さきに述べたと却りである，そのため，Piggott の理論式 によってる緎維の体積割合が直線的に変化している. 10 vol\% 括よび 15 vol\% のタングステン線を含を複合体では Piggott の理論式によると引張強さは $18.8 \mathrm{~kg} / \mathrm{mm}^{2}, 22.0$ $\mathrm{kg} / \mathrm{mm}^{2}$ という值となる。この值は非常に高く，連続瀻維 によって強化された場合を計算してみると，10vol\%で $14.3 \mathrm{~kg} / \mathrm{mm}^{2}, 18.3 \mathrm{~kg} / \mathrm{mm}^{2}$ となる連続䋐維に上って強化 されたものよりも大きい原因として，タングステン線のヤ ング率が複合体作製時に変化しないものとして取り报った 結果と思われる。
一方 Kelly のモデルから計算した複合体の強さはそれ

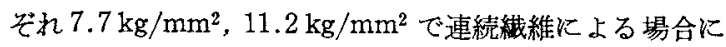
比べると、アスペクト比が 35 で臨界アスペクト比が 13.7 であるので，連続䋐維を含を場合の $61 \%$ の强さしか得ら れないことになる。実際に得られた複合体の強さは $10 \mathrm{vol}$ \%のときには $13.2 \mathrm{~kg} / \mathrm{mm}^{2}, 15 \mathrm{vol} \%$ のとさには $16.2 \mathrm{~kg} /$ $\mathrm{mm}^{2}$ であり, $10 \mathrm{vol} \%$ のときには $5.5 \mathrm{~kg} / \mathrm{mm}^{2}, 15 \mathrm{vol} \%$ のときでる $5 \mathrm{~kg} / \mathrm{mm}^{2}$ で Kelly の非連続䋐維の理論より 上回っていて，連続縺維を含む場合の $90 \%$ の割合で強化 されている。これは実験上の誤差として取り扱5のには大 きすぎる值で，やはり elasticな応力伝達の割合がアスペ クト比の小さいるのでるかなり大きく作用していると考え るのが妥当であると思われる．

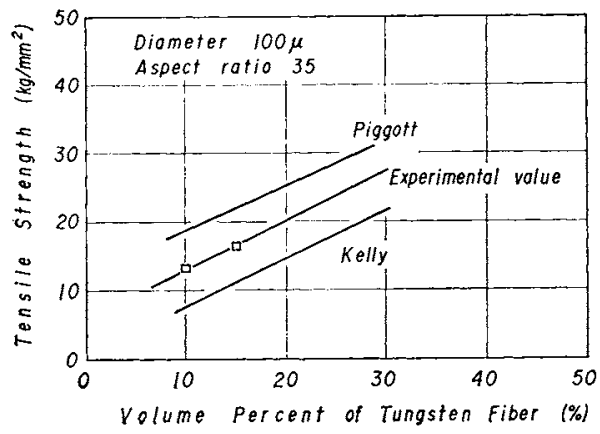

Fig. 6 Comparison for experimental value, and the theoretical values derived from Kelly's and Piggott's theory

IV. 㗭

マトリックスとしてアルミニウム䈾を用いて，フルミニ ウム箈を重权合わせ，その間にタングステン線を入れて压 延によって接合させ，その厓延加工度を変えることにより タングステン線のアスペクト比を変えた複合体を作製し， これらの複合体について引張試験を行ない，つぎのような 結果を得た。

緎維のアスペクト比がかなり小さいものでる強化の効果 がありこのことは Kelly の提案しているモデルでは説 明不十分と考光られ，このよ5にアスペクト比の小さい織 維を含む複合体では elastic な応力の伝澾が大きい役割を 果たすのではないかと考兄られることを示した。

この研究の遂行に協力した飯島一法君，井筒か注る君に 深く感謝の意を表します。 